\title{
TRANSLANGUAGING AS AN INSTRUCTIONAL STRATEGY IN ADULT ESL CLASSROOMS
}

\author{
Mehedi Hasan \\ York University \\ mehedi414@yahoo.com
}

\author{
A. B. M. Shafiqul Islam \\ King Khalid University \\ shafiqju30@gmail.com \\ Israt Jahan Shuchi \\ King Khalid University \\ ijshuchi@yahoo.com
}

\begin{abstract}
The use of learners' first language (L1) in adult second (L2/SL) or foreign language (FL) classrooms has always been a bone of contention over the past few decades. Many are in favor of L1 use terming it as having a constructive and facilitating role in language learning while some are against that practice and identify the use of L1 as a hindrance to the teaching and learning of a language. Of late, the concept of translanguaging has added a new dimension to this long-standing debate of using L1 in teaching/learning L2 since it basically insists on viewing languages as a single unitary system as opposed to the traditional linguistic perception of L1 versus L2. However, there have only been a very few studies on translanguaging with particular emphasis and attention given to ESL/EFL adults at the college/university level. This review article thus attempts to shed light on the theoretical underpinnings of this L1-L2 dichotomy and discuss how translanguaging differs from the customary notion of using L1 in adult L2 classrooms. This paper uses a qualitative research method that exclusively uses the relevant secondary references/works available on the topic. The literature demonstrated that both translanguaging and the notion of L1use in the L2 classroom are pedagogically similar as both allow the use of L1 in L2 classrooms at varying degrees though theoretically, they are different.
\end{abstract}

Keywords: Translanguaging, L1 use, adult L2 classroom, unitary system

\section{BACKGROUND}

The role of the first language (L1) in the adult second (L2/SL) or foreign language (FL) classrooms has witnessed a continuous shift over the past few decades. Since the beginning of the 20th century, the 'English only' approach 
emerged and got popularity worldwide as a reaction to the traditional grammartranslation (GT) method which allowed translation from L1 to L2. By the end of the 20th century, some L2 theoreticians and researchers began questioning the possibility and validity of undesirable and unachievable native-like competence in L2 learning and thus opined that the use of L1 is beneficial and constructive for L2 learners. While some researchers argue for using L1 (Snorradóttir, 2014; Swain and Lapkin, 2000), others still argue against (Harbord, 1992; Auerbach, 1993) the use of L1 in adult L2 classrooms. However, some researchers argue for judicious and systematic (e.g., Cook, 2001; Swain et al., 2011 or limited use (5\%) of L1 (Atkinson, 1987) in teaching L2 to adults in the classrooms. There have been a plethora of research studies that deal with the teachers' and students' perceptions of using L1 in L2 classrooms and have found that both teachers and students are benefited from using L1 in their L2 development (Thomas and Collier, 2002; Tian and Hennebry, 2016) though some studies have proved otherwise.

Most recently, the notion of translanguaging has added a new dimension to this ongoing debate of using L1 in the teaching and learning of L2. It basically insists on viewing languages as a single unitary system as opposed to the traditional linguistic perception of L1 versus L2. Although translanguaging has arguably been accepted by many educators and is widely being practiced in bilingual/multilingual education settings/schools in North America and across Europe, it appears to have been used in a fewer adult English as a Second Language/ English as a Foreign Language (ESL/EFL) programs so far. The reasons for avoiding translingual practice in adult ESL/EFL programs are manifold. One reason could be that the adult ESL/EFL teaching is still dominated by the monolingual approach and the role of L1 in English classrooms is viewed with skepticism by many ESL/EFL teachers and students. Another reason which is based on an assumption is that children most benefit from translanguaging practice as they have a good grasp of languages and can develop multiple language competencies easily than adult learners (Williams, 2002). However, there is research that shows that translanguaging can help L2 learners construct their identities, develop a positive attitude towards L2 and maximize their learning outcome (Creese and Blackledge, 2015; Burton \& Rajendram, 2019). Recent researchers have examined translanguaging with $\mathrm{L} 2$ at different college/university ESL programs and tried to measure the effectiveness, learners' and teachers' attitudes and any potential challenges with adult learners. But the evidence is not conclusive whether monolingual or using L1 along with L2 or translingual approaches are the best pedagogical method in adult English language teaching.

This review study primarily introduces the very concept of translanguaging and its recent use in the arena of English language teaching and learning. Besides highlighting the theoretical underpinnings, this study's prime focus is on how translanguaging is similar to or different from the age-long notion of L1-L2 dichotomy in EFL/ESL classroom. This paper consists of 5 sections. The first section focuses on the theoretical underpinning of the traditional SLA theories of L1 and L2. The second section reviews the concepts of L1 use in L2 teaching methodologies. The third section discusses the translingual view of language teaching/learning in the ESL classroom. The fourth section discusses how translingual practice is similar to or different from traditional L1 use in L2 
classrooms. The fifth and final section summarizes the findings and proposes pedagogical implications for ESL/EFL teachers.

Although L1 or translanguaging in adult ESL classes has been in use for over two decades, only a few studies have focused exclusively on the theoretical basis of such practice. Most of the research on translanguaging has focused on the practice of L2 language and literacy development at the elementary level with very little attention given to ESL/EFL adults at the college/university level. In addition, there has been almost no research to show how the notion of L1 use in L2 classrooms is similar to or different from translanguaging. From all these perspectives, this study bears much significance.

This paper aims to investigate the following two research questions: 1) What is the theoretical basis of L1 use in adult L2 classrooms?; and 2) How is translanguaging different from the traditional concept of using L1 in the L2classroom?

Since the first question is exploratory in nature, we have not made any hypothesis or prediction. However, the following hypotheses regarding the second question have been formed: 1) Theoretically, the notion of L1 use in L2 classroom is different from translanguaging since in conventional English language teaching/learning, L1 and L2 are viewed as two separate systems while translanguaging looks at them as a one unitary system; and 2) Pedagogically, translanguaging and the notion of L1 use in L2 classrooms are similar as both allow the use of L1 in the classroom at varying degrees. In translanguging, no particular amount of L1 use is specified though in traditional English language teaching/learning moderate and judicious use of L1 is encouraged in L2 classrooms.

\section{METHOD}

This is a review article that makes use of the qualitative research method. Through review articles, the reviewers, while studying the already available materials, attempt to propose new research directions, reinforce support for prevalent theories and ascertain patterns among existing research studies. For academics, review articles provide an excellent overview of the current literature on a topic. As a review article, this study is based on the secondary references/works, including relevant articles and books which tend to reanalyze, interpret, or review the past available data on a subject matter. However, this research has not included all the materials available on the subject of the present research; instead, it attempts to find such literature that fits the topic and, therefore, follows a particular set of inclusion and exclusion criteria while selecting the research materials for review. Although we found that studies on translingualism in bilingual education are limited to the elementary, junior or high school level, the review for this paper focused only on the studies at university level adult ESL programs. The criteria are as follows:

1. We used peer-reviewed journal articles, books, unpublished $\mathrm{PhD}$ theses which were written during the last decade. However, a few studies published before 2010 were also reviewed for studying the theoretical background of relevant Second Language Acquisition (SLA) theories and research. 
2. We used the York University library database, Google Scholar, online free access peer-reviewed journals and unpublished theses as our data source.

3. We searched articles with keywords such as 'SLA theories in L1/L2 development', 'SLA theories for Translanguaging', 'using L1 in L2 classroom', 'translanguaging in adult L2 classroom', 'benefits and challenges of translanguaging in L2 classrooms, and 'teachers and students perceptions on translanguaging'. The reference list of selected articles was also used to find additional supporting information. The articles that answered the research questions were finally selected for the review of this paper.

4. We chose both conceptual articles and empirical studies for answering the questions. All findings and relevant information were recorded in a scrapbook with specific reference. We then looked for coherence among concepts to draw a general synthesis of the arguments.

\section{FINDINGS AND DISCUSSION}

\section{Translanguaging: Theory and Practice in Adult ESL Classroom}

Translingualism is a process where language users use their own languages as an integrated communication system. Although this term was first used in Wales in the 1980s, it became popular in the 2000s. Garcia (2009) defines translanguaging as "the act performed by bilinguals of accessing different linguistic features or various modes of what are described as autonomous languages, in order to maximize communicative potential' (García, 2009, p. 140). G. Lewis et al. (2012) state that translanguaging is rooted in Vygotsky's Zone of Proximal Development (ZPD), that learners can expand their knowledge based on their prior knowledge and interdependence of multiple languages enables the cross-linguistic transfer. Referring to contemporary research, the authors also note that translanguaging fits into the sociocultural theory of learning (G.Lewis et al. 2012, p. 645). Translanguaging is concerned about effective communication, function rather than form, cognitive activity and language production $(\mathrm{G}$. Lewis et al., 2012, p. 641). G.Lewis et al. (2012) also argue that translanguaging is additive by nature and encourages the pragmatic use of multiple languages by the speakers. Some applied linguists claim that it is not as additive but rather dynamic because they reject the notion of additive /subtractive bilingualism. Citing Williams (2003), G. Lewis et al. (2012) further mention that translanguaging is deeper than just code-switching as the process requires learners to interchange language, assimilate and accommodate information and negotiate meaning and understanding through deeper cognitive processing (G. Lewis et al., 2012, p. 644). The authors mention that translanguaging is more appropriate for children as they have a good grasp of multiple languages at the same time and they are vulnerable in the early stage of their learning. The authors also describe several benefits of translanguaging such as promoting a deeper understanding of the subjects, helping develop weaker languages, facilitate school links and cooperate and helping integrate fluent speakers in the early stages. They claim that translanguaging is a movement against monolingual and separatist language in the classroom that promotes cognitive and sociocultural practice in the process of teaching and learning (G. Lewis et al., 2012, p. 645). 


\section{Research Q1: Second Language Acquisition (SLA) Theories of L1 and L2}

The language theories, learning hypotheses and teaching approaches/methodologies have changed considerably over the years. The changing notion of language caused the modification of learning theories/hypotheses which ultimately transformed the teaching approaches/methods. As a result, the shift from 'English only' classroom practice to judicious use of L1 in the L2 classrooms was guided by the changing notion of learning theories, teaching methodologies and critical classroom pedagogies. Traditional SLA theories define L1 and L2 as two separate systems and such division determines the teaching/learning practices. Although there are differences and similarities between the acquisition of L1 and L2, the differences are highlighted more than the similarities. The differences between L1 and L2 acquisition play a vital role in each approach of teaching methodologies. Below are some of the key factors that are believed to be significantly different in the L1 and L2 acquisition processes thus affirming our hypothesis that L1 and L2 as two separate systems in the SLA process.

\section{Acquisition-Learning Hypothesis}

Krashen (1982) believes that adults' L2 learning happens in two ways: through acquisition and learning. Acquisition happens through the maximum exposure to the target language and when learners learn the language informally and implicitly whereas learning happens in a controlled environment through explicit instruction and formal linguistic knowledge development (p. 17). He further argues that learning does not become acquisitions. However, he claims that acquisition may happen in the classroom through proper input and focused practice. It is evident from Krashen's hypothesis that he viewed L1 and L2 as two separate phenomena which functions differently.

\section{The Critical Period Hypothesis}

A critical period is the period in which certain skills and behaviors for language acquisition function with great speed and ease. Lenneberg (1967) mentions that after critical period, natural acquiring disappears and L2/FL learners need to learn L2 through a "conscious and labored effort" (p. 176). Based on neurological and clinical evidence, he sets the period between 2 and 13 years of age. Although critical period hypothesis does not deny that an adult learner cannot reach native speaker level of proficiency, educators consider this factor as a potential hindrance in designing learning tasks such as pronunciation and fluency development.

\section{Lateralization}

Steinberg (1997) argues that human brain loses its plasticity at around the age of 2 and becomes lateralized. As a result, the brain assigns certain structures and functions to certain hemispheres of the brain. Language, logical and analytical operations, and higher mathematics, for example, generally occur in the left hemisphere of the brain, while the right hemisphere is superior at recognizing emotions, recognizing faces and taking in the structures of things globally without analysis (p.179). Such argument posits that learners can easily acquire fluent 
control of the second language or native-like pronunciation before their brain is lateralized. This factor can also be compared to psychomotor factors which claims that as learners become older, their muscle loses flexibility and fail to reach native like pronunciation level in their L2 (Brown,1994).

\section{Affective Filter}

According to Krashen, (1982) an adult learner's L2 learning can be inhibited by several factors such as stress, anxiety, inhibition, language ego, attitudes etc. which block access to language acquisition. Unlike young learners, adult learners possess all those filters for which they lack confidence and feel unmotivated in learning an L2. The more the filters go up, the fewer chances are that the learners would learn the language effectively. Krashen's model stimulated debate among researchers as lacking empirical evidence and explanatory power but it still occupies an important place in adult L2 teaching/learning theories.

\section{Interlanguage: (IL)}

Selinker (1972) defines interlanguage as a leaner's "attempted product of target language norm" (p. 214). Bialystok and Sharwood Smith (1985) give a similar definition and mention that interlanguage is the linguistic performance of L2 learners "who achieved sufficient levels of analysis of linguistic knowledge" (p. 101). The interlanguage definition is based on learners L2 developing system and highlights what learners are not capable of doing.

\section{Fossilization}

Selinker (1972) coined the term fossilization to refer to the aspects of the learners' interlanguage that appear to remain permanently fixed as a nonnative like structures or sounds. He observes that "speakers of a particular L1 tend to keep in their interlanguage (IL) relative to a particular target language (TL), no matter what age of the learner or amount of explanation and instruction he receives in the TL" (Selinker, 1972, p. 215). The possible factors for fossilization have been mentioned as age, lack of motivation, communicative pressure, lack of learning opportunities, and the nature of corrective feedback (Ellis, 1994). The factors related to fossilization indicate that fossilization is unique to L2 acquisition whereas fossilization to L1 is rarely possible.

In addition to the above theoretical grounds, researchers mentioned other issues that make L1 and L2 different. Ellis (1994) stated some other factors that make learners L1 and 12 more different. For example, L2 learners as a language minority learner, status of other languages in the L2 learners' home country, medium of instruction in L2 learner's education system, the role of mother tongue in the sociological context of the L2 learners and L2 learner's choice of language variety also contribute to the L2 learner's development of language.

All of the above theories suggest that the factors or situation occur only with L2 learners. The social and contextual environment of L1 learners makes it easier for them to learn and use the language in a natural way and any deviation because of the above factors is not considered as failure. However, for an L2 learner, the above factors are considered seriously and L2 learners' failure is viewed as a deficit. 


\section{Role of L1 in Teaching Methodologies}

Above theories and perspectives of L1 and L2 influence the role of L1 English language teaching/learning methodologies till today. For many years, the use of L1 in L2 classrooms was considered a 'forbidden fruit' and believed to hinder the L2 learning process. Many ESL/EFL teachers believe that the target language should be the language of the classroom (Richards and Rodgers, 2012).

In this section, using the book Approaches and Methods in Language Teaching by Richards and Rodgers (2012), we will discuss what role L1 plays in different English language teaching methodologies. In Direct Method, lessons are done entirely in the target language and emphasis is given on language learning by direct contact with the foreign language in meaningful situations and hence, L2 learners are not allowed to use their L1. In the Grammar-translation method, L2 learners rely on translating to the learner's first language and vice versa. The Audio-lingual method prohibits the use of L1 and all teaching/learning are conducted in L2. The Total Physical Response method stresses the importance of aural comprehension and has no room for L1 use in the classroom. In the Silent Way, teachers speak as little as possible so that the learners can be in control of what they want to say and therefore no use L1 is made. The Communicative Approach which is also known as the functional-notional approach in the European framework emphasizes language learning through interaction, language use, peer and group activities, and learning both the grammatical forms and their functions. The Communicative Approach proposes judicious use of the L1 in L2 / foreign language learning. Communicative Language Teaching views the L1 as a tool that can be used to check the students ' understanding of the second /foreign language. The Natural Approach, although encourages maximum exposure to L2, puts emphasis on identifying the similarities between learning L1 and L2.

All the above approaches/methods indicate that most of the previous methodologies prohibit the use of L1 in L2 classrooms on the assumption that using L1 is debilitating for L2 learning. Only some recent methodologies allow the use of L1 as a facilitating tool in L2 classrooms. However, all English language teaching methodologies view L1 and L2 as two separate systems that interact either positively or negatively with the L2 learning process.

\section{Arguments against L1 Use}

The major argument for 'English only' classroom is derived from Krashen's input hypothesis (Krashen, 1982, p. 20). According to Krashen, the most effective way to increase L2 is to expose the learners to comprehensive input. He argues that if a learner is given enough input, the necessary language information would automatically be provided. In order to get maximum output in L2, learners should be given comprehensive input in their L2. Therefore, giving instruction in L1 decreases the amount of L2 output and thus may impact maximum L2 acquisition possibilities. Although most of the contemporary researchers followed Krashen's hypothesis, some researchers also argued for using L1 with low-level language learners (Krashen \& Terrell, 1983; Chambers, 1991). For many years, 'English only' approach has faced several challenges such 
as lack of trained teachers, culturally appropriate materials and unmotivated learners, and hence, researchers have started to advocate for L1 use in the L2 classrooms, especially in FL classrooms.

\section{Argument for L1 Use}

As the L1-only classroom started facing many challenges and new learning theories emerged in the 1990s, the notion of L1-only classroom also changed. Vygotsky's Cognitive and Sociocultural Theory (CST) and Cummins' Linguistic Interdependence Hypothesis (LIH) are two major theories that support the use of L1 in the L2 classroom. According to Vygotsky, students learn through building a relationship with the teacher and their peers. He believes that a learner learns a language at the social and individual level through interaction. Vygotsky describes that a learner has a kind of developmental distance between what he/she can do or what he/she cannot do. He claims that through collaboration and interaction, a learner can advance to a higher level what he terms as the development Zone of Proximal Development (ZPD). According to him, scaffolding or the "support structure to get to the next level" is a major factor for language development which also occurs in ZPD (Hummel, 2014, p. 91). For this reason, CST claims that learners' L1 can be used to stimulate cognition, interaction and scaffolding ideas for developing L2.

Cummins' LIH (1991) suggests that L1 and L2 are not two separate systems but they are interdependent psychologically. Cummins theorizes that L1 and L2 may appear different at the surface level but deep within these two operate through the same process and it is possible to "transfer of cognitive/academic or literacy-related proficiency from one language to another" (Cummins, 2007, p.232). He also claims that learners' L2 competence is related to their L1 competence, that is, the more a learner is competent in their L1, the more she/he is likely to develop in L2. The above two theories assumed that using L1 in the L2 classroom is beneficial for learners to some extent.

As there is "neither a scientific nor a pedagogical reason to exclude L1 from the teaching process", (Spahiu, 2013), some research studies advocated for using L1 in L2 classrooms for different purposes. Yavuz (2012) proposes several uses of L1 in L2 classrooms. He mentions that L2 teachers can use L1 to elicit language, check comprehension, give complex instruction to basic level learners, check for sense, test, and develop circumlocution strategies. Levine (2012) believes that using L1 in L2 classrooms can facilitate function, clarify the meaning, structure and organize communication, foster interpersonal dynamics, reduce anxiety and validate learner identity. Zulfikar (2019) suggests that using L1 can help learners explain or clarify concepts, tasks, assignments, instructions or activities. He believes that L1 can stimulate collaborative dialogue and save classroom time. The study of Shuchi and Islam (2016) deals with students' and teachers' perceptions of using L1 in L2 classrooms in Saudi Arabia and Bangladesh and finds that using L1 is useful to explain a difficult concept, to make a comparison between L1 and L2, to clarify instructions to low-level learners, to reduce anxiety, and to build rapport with learners. All of the researchers argue for the judicious use of L1.

In sum, it can be argued that the majority of the research studies suggest L1 use for setting up an activity, going over direction, giving homework, maintain 
decline, for the sophisticated explanation of items such as grammar with lowerlevel learners to reduce anxiety and facilitate learning.

\section{Research Q2: Differences between Translanguaging and the Traditional Notion of L1 Use in L2 Classrooms?}

Translingualism has a fluid view of language and differs from the traditional view of L1 use in the L2 classroom. In the field of English language teaching (ELT), the principles and practices of any teaching pedagogy are determined by the educational psychology, learning theories, and sociopolitical perspectives of that particular era. For example, in the early 20th century, applied linguists described language from a structuralist approach and this approach later contributed to developing a grammar based language learning approach. The structuralist approach was believed to provide an "effective and theoretically sound basis" for the audiolingual method (Richards and Rodgers, 2014, p. 1). Likewise, 'communicative competence' advocated by Hymes eventually gave birth to Communicative Language Teaching (CLT) in the 1980s. Build upon four competencies (Grammatical, Sociolinguistic, Discourse and Strategic) and three learning principles (communication; task, and meaningfulness) (as cited in Brown and Lee, 2015, p. 30), CLT method is often characterized by fluency and accuracy, the relationship of form and function, focus on real-life context, learners' autonomy and student-centered classroom.

There was a rapid change of learning theories/hypotheses and teaching approaches/methods in the late $20^{\text {th }}$ century. CLT, which was well-received across the world in the 1990s, was later being criticized as rooted in "western origin" which does not fit in non-western cultures (Brown and Lee, 2015, p. 34). Influenced by Vygotsky's ZPD, Lantolf (2000) and Lanatolf and Phoener (2008) used the term sociocultural theory (SCT) which basically argues that there is "no objective source for our knowledge and that knowledge is itself a social contract" (as cited in Hummel, 2014, p.93). As a result, Post method pedagogy emerged in the 2000s (Richards \& Rodgers, 2014). Post method suggests to put away all the limited concept of method and proposed a "pedagogy of particularity" which demands that ESL teachers recognize the diversity of the modern world and "blend and tailor tasks" appropriate for specific groups "in a specific geographical, social and political context" (Brown and Lee, 2015, p. 40). Ford (2009) while arguing the reasons for changing roles of L1 in L2 classroom in Japan claims that such change was also influenced by Philipson's linguistic imperialism (Philipson, 1992), the notation of voice (Pennycook,1994), participatory pedagogy and education (Auerbach, 2000) (Cited in Ford, 2009, pp. 63-64). It is evident from the above literature that the pedagogical strategies in ELT evolved based on the physical, cognitive and language development theories of the time which ultimately influenced the notion of the use of L1 in the L2 classroom.

In education, monolithic approach was dominant for centuries and there was no room for accommodating the diversity and differences among various ethnic and cultural groups. According to Stille and Cummings (2013), the social, cultural, technological change such as new context, mobility, networks for 
communications, language practice for individuals and communities has given birth to the notion of plurilingualism (p. 630). To address the changing perspective of time, the notion of translanguaging played a vital role by providing a more inclusive instructional strategy in current educational system. Rooted in Grosjean's idea of bilingualism, translanguaging argues that "bilinguals are not simply two or monolinguals contained in one individual, these models generally view the family languages as separate entities, rather than as part of a single linguistic repertoire" (Mazzaferro, 2018, p.51). Stille and Cummings (2013) further elaborate this idea by referring to several research studies. The researchers claim that the notion of plurilingualism focuses attention on subjectivity, agency, and social context. They also contend that learners' plurilingual identities are "open, shifting, and emergent in everyday activities, and shaped by and within the practices and pedagogies of the classroom" (p. 631). According to them, plurilingualism is a paradigm shift which reveals the underlying biases and assumptions of monolingualism. Viewing L1 and L2 separately is constructed under the perceptions that the L2 learners are 'others', 'different', 'deficient', 'struggling' in an idealized monolingual world.

The above literature indicates that the traditional concept of L1 use in L2 classroom and translanguaging are rooted in the same sociolinguistic and psychologistic theories. However, they are significantly different in terms of linguistic viewpoint and pedagogical implications in the classroom. The former emerged to facilitate L2 teaching/learning and the latter came into being to facilitate bi/multi/plurilingualism and to help learners adapt to the dynamic socioeconomic and political world system. Although both approaches support the use of L1 in L2 classrooms at varying degrees, the traditional applied linguists view L1 and L2 as two separate systems whereas the translanguaging views language as an inseparable unitary system. Hence, it could be argued that the notion of L1 use in L2 and translanguaging evolved from two different streams at two different times. However, it appears that both streams meet at a certain point with one common goal. For example, prescriptive grammar based on structuralist linguistics used to view language as a prescriptive, concrete, formulaic combination of structures and rules but functional linguistics based on language in social practice views language as a descriptive, abstract, and transformative in context. The latter position thus gets reverberated with translanguaging.

Therefore, we believe both ideas of using L1 in L2 classroom and translanguaging have one common purpose, that is, to accommodate all language learners by creating a space and using their funds of knowledge to learn through interaction, negotiation and reconciliation of identities. The following are the fundamental theoretical differences between the notion of L1 use in L2 classroom in English language teaching/learning and translanguaging in education.

\section{Monolingualism Vs Multi/Plurilingualism}

Traditional ESL classroom is based on the monolingual approach to teaching which is based on Chomsky's notion of naïve speaker model as an ideal listener-speaker. A monolingual approach views nonnative speakers' interlanguage or interference, facilitation, affective filters etc. as potential barriers to L2 learning. On the other hand, translanguaging views L2 learners' interlanguage, L1 competencies as part of their language repertoire and believes 
that such knowledge can contribute to the overall language development of L2 learners.

\section{Language Vs Languaging}

Chomsky's Universal Grammar (UG) and Bloomfield's structuralist linguistics view language as a code or a system of rules or structures and do not consider the social and individual differences in practice. Languaging, on the other hand, refers to the "simultaneous process of continuous becoming of ourselves and our language practices, as we interact and make meaning in the world". Citing Becker (1995), they mention that languaging is a new way of entering into the history of interaction and cultural practice. Referring to Mignolo (2000), the authors argue that language is not syntactic, semantic and phonetic rules rather a "strategies for orienting and manipulating social domains of interaction" (Garcia and Wei, 2018, p. 8).

\section{Code Switching Vs. Code Mixing and Codemeshing}

The traditional concept of using learners L1 in L2 classroom is viewed as code-switching, the practice of alternating between two or more languages or between varieties of a language during a conversation. However, in code-mixing and code meshing, "multilingual speaker engages with the shifting and fluid situations in everyday life to learn strategies of negotiation and adaptation for meaning-making" (Canagarajah, 2007, p.933). Therefore, through code-mixing and code meshing, L2 learners acquire the target language form through a unitary language system.

\section{Linguistic Construct Vs Socio-political Construct}

In traditional SLA theories, language conspires as an idiolect or a series of structural and lexical features that a speaker of a particular language uses. Conversely, "translanguaging refers to using one's idiolect, that is, one's repertoire without regard for socially and politically defined language labels or boundaries" (Otheguy et al., 2015, p.297). Whereas traditional language teaching is code bounded and embedded in specific communication activities, translanguaging is a trans-semiotic system with many meaning-making signs such as speech, gesture, gaze and other signs (García \& Li Wei, 2018, p. 42).

\section{Monolingual Communicative Practice Vs Transformative Communicative Practice}

Traditional ESL teaching practises monolingual communicative practice where learners are expected to develop their four skills through communication in English. Translingual communicative practice, on the other hand, is created in a situation where learners are multilingual and their personal experiences, environments, history, attitude, belief, ideology, cognitive and physical ability intersect. Wei (2011) points out that such practice is "flouting the rules and norms of behavior including the use of language" (p.1223).

\section{Process Vs Product}


Traditional English language teaching primarily focuses on student products. Language competence or language skill is assessed based on the preconstructed structure of individual performance in a task. However, in translanguaging, language competence is often aligned with accommodation which includes negotiation strategies and meaning-making processes in a particular contact situation (Canagarajah, 2013, pp. 191-92).

\section{Implications of Translanguaging for Adult ESL Teachers/Learners}

In this age of super mobility and super-diversity, SL/FL teachers should consider how language functions in real life and teach what is needed for learners. SL/FL teachers should not view and analyze learner's linguistic competence solely in terms of target language (TL); rather they should use student's multicompetence in learning. ESL teachers should also consider the translingual idea of performative competence and focus on learners' ability to communicate using multilingual and multimodal resources. SL/FL teachers can engage learners in multilingual group discussions, allow students to brainstorm ideas for pre-tasks and allow them to use their cultural background to co-construct knowledge. Teachers also need to educate learners about the benefit of their L1 and the funds of knowledge they bring into the classroom, talk about human diversity and identity formation, and discuss critical pedagogy with students. Adult learners usually like to discuss and share their personal feeling around language teaching biases and policies. Therefore, teachers can use their natural curiosity to engage them in translanguaging tasks and activities.

Although SL/FL researchers have talked about recognizing and legitimizing English language varieties as World Englishes or Lingua Franca English, there have been biases towards nativespeakerism and Standard English and continuous resistance towards a more inclusive polylithic approach. SLA theories, despite having strong counter-arguments, are regarded highly as the foundation for creating SL/FL syllabus and designing materials and tasks. Linguistic competence is defined in terms of native standard and both learners and teachers aspire for native-like competence. As a result, teachers and students should be made aware of such pervasive language ideologies and policies and work together towards a paradigm shift to make a balanced and decolonized power system.

\section{CONCLUSION}

Translanguaging is relatively a new idea in ESL/EFL teaching /learning. Translanguaging and the notion of L1 use in the L2 classroom evolved at two different times (the former in the 1980s and the latter in the1990s) in two separate branches (in bilingual education and in applied linguistics) of education. Although both strategies were influenced by the contemporary educational psychological principles/ theories, they have distinctive perspective in the use of L1 in the classrooms. But both translanguaging and the traditional notion of L1 use in L2 classrooms have one thing in common that is they advocate for the use of L1 in SL/FL classrooms though in a limited franchise. Therefore, there could be 
resistance from researchers, teachers and students against such practice. This also suggests that a further research is required to investigate the scope, challenges and benefits of translanguaging in adult ESL/EFL classrooms. The translanguaging pedagogy is still somewhat fluid, developing and both teachers and students do not have sufficient knowledge about the nature of tasks and activities that might be performed in the classroom. Therefore, it is assumed that it will take some time to shift paradigms and adopt such new practices in adult English Language Teaching.

\section{REFERENCES}

Atkinson, D. (1987). The mother tongue in the classroom: A neglected resource? ELT journal,41(4), 241-247.

Auerbach, E. R. (1993). Reexamining English only in the ESL classroom. TESOL Quarterly, 27(1), 9-32.

Bialystok, E \& Smith, M.A.S. (1985). Interlanguage is not a state of mind: An evaluation of the construct for second- language acquisition. Applied Linguistics. 6. 10.1093/applin/6.2.101.

Brown, H. D. (1994). Principles of language learning and teaching (3rd ed.). USA: Prentice Hall Regents.

Brown, H. D., \& Lee, H. (2015). Teaching by principles: An interactive approach to language pedagogy (Fourth ed.). White Plains, NY: Pearson Education.

Burton, J., \& Rajendram, S. (2019). Translanguaging-as-Resource: University ESL Instructors' Language Orientations and Attitudes toward Translanguaging. TESL Canada Journal, 36(1), 21 - 47. https://doi.org/10.18806/tesl.v36i1.1301

Canagarajah, A. S. (2007). Lingua Franca, Multilingual Communities, and Language Acquisition. Modern Language Journal, 91, 923-939.

$\begin{array}{llll}\text { Canagarajah, } & \text { A. } & \text { S. } & \text { (2013). }\end{array}$ practice.NewYork/Abingdon,UK:Routledge.

Cook, V. (2001). Using the first language in the classroom. Canadian Modern Language Review, 57(3), 402-423.

Creese, A., \& Blackledge, A. (2010). Translanguaging in the bilingual classroom: A pedagogy for learning and teaching? The Modern Language Journal, 94, 103-115.

Chambers, F. (1991). Promoting use of the target language in the classroom. Language Learning Journal, 4(1), 27-31.

Cummins, J. (1991). Interdependence of first-and second-language proficiency in bilingual children. In Bialystok, E. (Ed), Language processing in bilingual children (pp. 70-89). Cambridge: Cambridge University Press.

Cummins, J. (2007). Rethinking monolingual instructional strategies in multilingual classrooms. Canadian Journal of Applied Linguistics, 10(2), 221-240.

Ellis, R. (1994). The study of second language acquisition. China: Oxford University Press. 
Ford, K. (2009). Principles and Practices of L1/L2 Use in the Japanese University EFL Classroom. JALT Journal JALT Journal 31.1, 31(1), 63. doi:10.37546/jaltjj31.1-3

Garc1'a,O. (2009b). Education, multilingualism and translanguaging in the 21st century. In A.K. Mohanty, M. Panda, R. Phillipson, \& T. Skutnabb-Kangas (Eds.), Multilingual education for social justice: Globalising the local (pp. 128-145). New Delhi, India: Orient BlackSwan.

García, O., \& Wei, L. (2018). Translanguaging: Language, bilingualism and education. Basingstoke: Palgrave Macmillan.

Harbord, J. (1992). The use of the mother tongue in the classroom. ELT journal, 46(4), 350-355.

Hummel, K.M. (2014). Introducing Second Language Acquisition: perspectives and practices. S.1.: JOHN WILEY \& SONS.

Krashen, S. (1982). Principles and practicein second language acquisition. Oxford: Pergamon.

Krashen, S. D., \& Terrell, T. D. (1983). The natural approach: Language acquisition in the classroom. Oxford: Pergamon.

Lenneberg, E.H. (1967). Biological Foundations of Language. New York, John Wiley and Sons.

Levine, G. S. (2012). Principles for code choice in the foreign language classroom: A focus on grammaring. Language Teaching,47(3),332-348. doi:10.1017/s0261444811000498

Lewis, G., Jones, B., \& Baker, C. (2012). Translanguaging: Origins and development from school to street and beyond. Educational Research and Evaluation: An International Journal on Theory and Practice, 18(7) 37-41.

Mazzaferro, G. (2018). Translanguaging as everyday practice. Cham, Switzerland: Springer.

McLaughlin, B. (1991). Theories of second-language learning. Great Britain: Arnold.

Otheguy, Ricardo \& García, Ofelia \& Reid, Wallis. (2015). Clarifying translanguaging and deconstructing named languages: A perspective from linguistics. Applied LinguisticsReview.6.281-307. 10.1515/applirev-20150014.

Richards, J. C., \& Rodgers, T. S. (2012). Approaches and methods in language teaching (2nd ed.). Cambridge: Cambridge University Press.

Selinker, L. (1972), Interlanguage. International Review of Applied Linguistics, 10, 209-231.

Shuchi, I. J., \& Islam, A. B. (2016). Teachers' and Students' Attitudes towards L1 Use in EFL Classrooms in the Contexts of Bangladesh and Saudi Arabia. English Language Teaching, 9(12), 62-72. doi:10.5539/elt.v9n12p62

Snorradóttir, A. B. (2014). Language use in the English classroom: the role of students' first language in grades 9 and 10 in English classrooms in Iceland (unpublished Bachelor's thesis). University of Iceland, Reykjavík, Iceland.

Spahiu, I. 2013. Using Native Language in ESL Classroom, IJ-ELTS: International Journal of English Language \& Translation Studies. 1 (2), 243- 248.

Steinberg, D. D. (1997). An introduction to psycholinguistics. USA: Longman.

Stille, S., \& Cummins, J. (2013). Foundation for Learning: Engaging Plurilingual Students' Linguistic Repertoires in the Elementary Classroom. TESOL 
Quarterly, 47(3), 630-638. doi:10.1002/tesq.116

Swain, M., Kirkpatrick, A., \& Cummins, J. (2011). How to Have a Guilt-free Life Using Cantonese in the English Class: A Handbook for the English Language Teacher in Hong Kong. Hong Kong: Research Centre into Language Acquisition and Education in Multilingual Societies, Hong Kong Institute of Education.

Swain, M., \& Lapkin, S. (2000). Task-based second language learning: The uses of the first language. Language teaching research, 4(3), 251-274

Thomas, W.P., \& Collier, V.P. (2002). A national study of school effectiveness for language minority students' long-term academic achievement. Santa Cruz, CA: Center for Research on Education, Diversity and Excellence, University of California-Santa Cruz.

Tian, L., \& Hennebry, M. (2016). Chinese learners' perceptions towards teachers' language use in lexical explanations: A comparison between Chinese-only and English-only instructions. System, 63, 77-88.

Wei, L. (2011). Moment Analysis and translanguaging space: Discursive construction of identities by multilingual Chinese youth in Britain. Journal of Pragmatics, 43(5), 1222-1235. doi:10.1016/j.pragma.2010.07.035

Williams, C. (2002). Ennill iaith: Astudiaeth o sefyllfa drochi yn 11-16 oed [A language gained:A study of language immersion at 11-16 years of age].

Bangor, UK: School of Education. Retrieved fromhttp://www.bangor.ac.uk/addysg/publications/Ennill_Iaith.pdf

Yavuz, F. (2012). The Attitudes of English Teachers about the Use of L1 in the Teaching of L2. Procedia-Social andBehavioral Sciences,46,4339-4344. doi:10.1016/j.sbspro.2012.06.251

Zulfikar, Z. (2019). Rethinking the Use Of L1 in L2 Classroom. Englisia Journal, 6(1), 42-51. doi:10.22373/ej.v6il.2514 